\title{
Assessment of Erythropoietin Levels and Some Iron Indices in Chronic Renal Failure and Liver Cirrhosis Patients
}

\author{
Essam Mady ${ }^{1,2, \#}$, Gehane Wissa ${ }^{1}$, Ali \\ Khalifa $^{2}$ and Mahmoud El-Sabbagh ${ }^{1}$ \\ ${ }^{1}$ Department of Biochemistry, Faculty of Sci- \\ ence, Ain Shams university, Cairo, Egypt \\ ${ }^{2}$ Oncology Diagnostic Unit, Department of \\ Biochemistry, Faculty of Medicine, Abbassia, \\ Cairo, Egypt
}

\begin{abstract}
This study was constructed to investigate the relationship between renal anaemia and erythropoietin (EPO) concentrations in chronic renal failure (CRF) patients and to evaluate the possible role of the liver. Serum EPO levels were measured in blood samples from $20 \mathrm{CRF}$ patients on hemodialysis (HD), 20 liver cirrhosis (LC) patients, 20 patients having both CRF and LC and undergoing HD, and 20 normal control subjects. Blood cell counts, iron indices (iron, total iron-binding capacity (TIBC) and ferritin), renal function (blood urea nitrogen (BUN) and creatinine), hepatic function (ALT, AST, ALP and bilirubin) investigations were carried out for all the subjects enrolled in this study. CRF patients without LC had serum EPO concentration of $6.21 \pm 0.53 \mathrm{mU} / \mathrm{ml}$ (mean $\pm \mathrm{SE}$ ), which was significantly higher than that in patients having both CRF and LC (4.32 \pm 0.52$)$ $(\mathrm{p}<0.01)$. Both groups showed significantly lower values than the controls $(12.75 \pm 0.70)(p<0.001)$. LC patients with intact kidneys had significantly higher EPO level $(22.70 \pm 1.70)(\mathrm{p}<0.001)$. No correlation was found between EPO level and any of the hematologic or iron indices.
\end{abstract}

KEYWORDS: Erythropoietin, iron indices, chronic renal failure, liver cirrhosis

\footnotetext{
\# Correspondence: Dr. E.A. Mady, Faculty of Education, King Faisal University, PO Box 1759, Al-Hassa 31982, Saudi Arabia.
}

\section{INTRODUCTION}

Chronic renal failure (CRF) develops due to irreversible renal function deterioration as a consequence of destruction of over $80 \%$ of the nephrons. End-stage renal disease (ESRD) is finally reached when more than $90 \%$ of the nephrons have been destroyed, and renal function has become impaired to life-threatening extents. Regular dialysis is then essential to sustain life $[1,2]$.

Renal anaemia is of multifactorial etiology. The main factor, however, is decreased erythropoietin (EPO) production by the failed kidneys [3-9].

EPO is a hematopoietic glycoprotein hormone, synthesized primarily in the kidney by peritubular interstitial fibroblasts. $10-15 \%$ of the circulating hormone is produced externally in the liver by both the hepatocytes and other cells (lipocytes, stellate cells or perisinusoidal cells) [10-14]. Erythropoietin controls erythrocyte production. This action is mediated by specific receptors on the surface of the burst-forming unit-erythroid (BFU-E) and colony-forming uniterythroid (CFU-E) cells, where the EPO-receptor complex is responsible for progenitor cell development into mature erythrocytes. More over, EPO prevents programmed cell death of BFU-E and CFU-E [15].

Under normal steady-state conditions, the concentration of circulating EPO is regulated mainly by $\mathrm{Hb}$ concentration, and is sufficient to maintain the red cell mass and replace senescent and dying erythrocytes. In CRF, the adaptation of EPO levels to $\mathrm{Hb}$ concentration is lost, EPO production is seriously disturbed and its levels are much lower than those observed in non-renal anaemias of 
comparable severity. Hepatically produced EPO is evidently of no compensatory value [16-19].

The present study aimed to investigate the relationship between the state of kidney and liver in CRF and/or LC patients, the level of EPO and the development and/or regression of anaemia.

\section{SUBJECTS AND METHODS}

\section{Subjects}

This study was conducted on 60 adult male patients: 20 with CRF with a mean age of $51.95 \pm 1.66$ years (mean $\pm \mathrm{SE}$ ), 20 with LC with a mean age of $52.05 \pm 2.08$ years and 20 with both CRF and LC with a mean age of $52.40 \pm 1.40$ years along with 20 normal male control subjects with a mean age of $50 \pm 2.22$ years. The patients were chosen from the Dialysis Unit and Internal Medicine Department in Ain Shams University Hospital in Cairo, Egypt in the period from January 1994 to May 1995. The control subjects were thoroughly investigated and were confirmed to be free of any renal or hepatic abnormalities. All the CRF patients were undergoing HD for four hours, twice a week. No cases of polycystic kidney disease or diabetic nephropathy were included in this study. The clinical investigations of all the patients confirmed that they suffered only from CRF and/or LC. They had been suffering from these disorders for at least five years before carrying out this study.

\section{Methods}

Samples of venous blood were withdrawn from subject after having fasted for twelve hours. For the hemodialysis patients.the samples were withdrawn just before starting dialysis. The hematologic assays were performed and calculated according to the manual standard methods [20]. The renal and hepatic function assays were performed using Synchron CX5 Clinical System (Beckman, USA). Serum iron and TIBC were measured manually using the standard colorimetric method [21]. Serum ferritin was assayed im- munologically [22] using the microparticle enzyme immunoassay (MEIA) technique (Abbott Laboratories, Diagnostic Division, USA). EPO was assayed immunologically [23] by radioimmunoassay (RIA) (Diagnostic Systems Laboratories Inc., USA). The results were analyzed using SPSS package (Echo Soft Corp., USA, 1993). TLC, Hb, PCV, MCV, MCH, MCHC, platelet count, ALT, iron, TIBC and EPO were $\log$ transformed to approximate normal distribution.

\section{RESULTS}

Renal function. The CRF patients with and without LC showed significantly elevated BUN and creatinine levels compared with the controls $(\mathrm{P}<0.001)$ (Table 1). The LC patients showed significantly decreased BUN levels compared with the controls, and consequently, with the other investigated patients groups $(\mathrm{P}<0.001)$, but showed non-significantly different creatinine levels from those of the controls $(\mathrm{P}<0.05)$, but significantly lower than those of the CRF patients with and without LC $(\mathrm{P}<0.001)$. The CRF patients who had also LC had significantly lower BUN and creatinine levels than those without LC ( $\mathrm{P}<0.01$ and $\mathrm{P}<0.001$ respectively).

Hepatic function. ALT, AST and total bilirubin showed significant elevations in the CRF subjects who also had LC, and in the LC patients compared with both the controls and the CRF subjects who did not have LC $(\mathrm{P}<0.001)$ (Table 1). This latter group showed nonsignificantly different levels from the controls $(\mathrm{P}>0.05)$. However, significantly higher levels were found in the CRF patients who had LC compared with the LC patients $(\mathrm{P}<0.001$ for ALT and total bilirubin, and $\mathrm{P}<0.05$ for AST).

Significantly elevated ALP levels were found in all patient groups compared with the controls $(\mathrm{P}<0.001)$. The CRF subjects who had LC had significantly higher levels than those of the CRF subjects who did not have LC $(\mathrm{P}<0.001)$ and the LC subjects $(\mathrm{P}<0.01)$, while the latter two groups showed no significant difference from each other $(P>0.05)$. A significant positive cor- 
Table 1

Statistical analyses of the results of the renal and hepatic functions in the main investigated groups

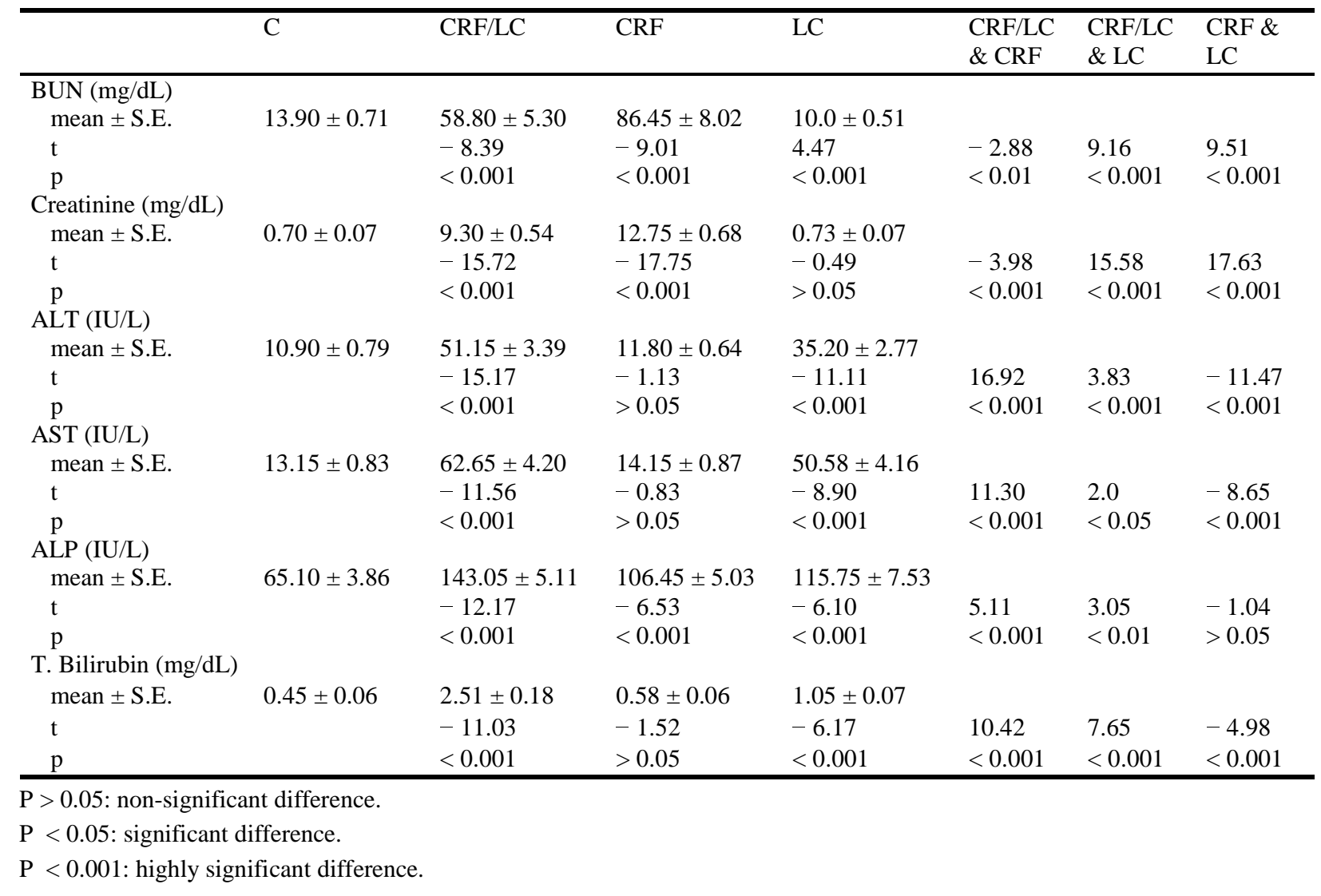

relation was found only between ALP and BUN in the CRF subjects who had also LC ( $\mathrm{r}=0.44938)$.

Hematological results. The hematological results showed parallel changes for RBCs, $\mathrm{Hb}$ and PCV in each single group. All the patients groups had significantly lower values than the control group $(\mathrm{P}<0.001)$ (Table 2).

Non-significant different MCV values were found in the CRF patients who had LC and the LC patients compared with the controls and with each other $(\mathrm{P}>0.05)$. However, the CRF patients who did not have LC showed significantly lower MCV values than the controls $(\mathrm{P}<0.01)$, the CRF patients having LC $(\mathrm{P}<0.05)$ and the LC patients $(\mathrm{P}<0.01)$.

The platelet count showed no significant changes among the CRF patients who had LC, the LC patients and the controls $(\mathrm{P}>0.05)$, but showed significantly low values in the CRF patients who did not have LC compared with the controls $(\mathrm{P}<0.001)$, the CRF patients who had LC $(\mathrm{P}<0.001)$ and the LC patients $(\mathrm{P}<0.01)$.

Iron indices. Serum iron levels were nonsignificantly different among the controls, CRF patients without LC and the LC patients ( $\mathrm{P}>0.05$ ) (Table 3). However, the CRF patients who had LC had significantly lower iron levels than both the controls and the CRF patients who did not have LC $(\mathrm{P}<0.05)$ but non-significantly different from those of the LC patients $(\mathrm{P}>0.05)$.

No significant change was found in TIBC among the controls and the CRF patients with and without LC (Table 3), but a significant decrease was found in the LC patients compared with the controls $(\mathrm{P}<0.01)$ and the CRF patients with and without LC $(\mathrm{P}<0.05)$. 
Table 2

Statistical analyses of the hematological results in the main investigated groups

\begin{tabular}{|c|c|c|c|c|c|c|c|}
\hline & $\mathrm{C}$ & $\mathrm{CRF} / \mathrm{LC}$ & $\mathrm{CRF}$ & $\mathrm{LC}$ & $\begin{array}{l}\text { CRF/LC } \\
\& \text { CRF }\end{array}$ & $\begin{array}{l}\mathrm{CRF} / \mathrm{LC} \\
\& \mathrm{LC}\end{array}$ & CRF \& LC \\
\hline \multicolumn{8}{|l|}{ TLC (x $\left.10^{9} / \mathrm{L}\right)$} \\
\hline mean \pm S.E. & $6.73 \pm 0.43$ & $7.29 \pm 0.55$ & $6.25 \pm 0.40$ & $6.85 \pm 0.50$ & & & \\
\hline $\mathrm{t}$ & & -0.57 & 0.88 & -0.10 & 1.32 & 0.51 & -0.80 \\
\hline $\mathrm{p}$ & & $>0.05$ & $>0.05$ & $>0.05$ & $>0.05$ & $>0.05$ & $>0.05$ \\
\hline \multicolumn{8}{|l|}{$\operatorname{RBCs}\left(\times 10^{12} / \mathrm{L}\right)$} \\
\hline mean \pm S.E. & $5.17 \pm 0.08$ & $2.66 \pm 0.17$ & $2.76 \pm 0.18$ & $3.42 \pm 0.21$ & & & \\
\hline $\mathrm{t}$ & & 13.81 & 12.5 & 7.83 & -0.39 & -2.85 & -2.42 \\
\hline $\mathrm{p}$ & & $<0.001$ & $<0.001$ & $<0.001$ & $>0.05$ & $<0.01$ & $<0.01$ \\
\hline \multicolumn{8}{|l|}{$\mathrm{Hb}(\mathrm{g} / \mathrm{dL})$} \\
\hline mean \pm S.E. & $14.25 \pm 0.17$ & $7.10 \pm 0.46$ & $7.21 \pm 0.46$ & $9.58 \pm 0.65$ & & & \\
\hline $\mathrm{t}$ & & 11.03 & 10.48 & 5.76 & 0.15 & -2.7 & -2.54 \\
\hline $\mathrm{p}$ & & $<0.001$ & $<0.001$ & $<0.001$ & $>0.05$ & $<0.01$ & $<0.01$ \\
\hline \multicolumn{8}{|l|}{ PCV (\%) } \\
\hline mean \pm S.E. & $43.05 \pm 0.51$ & $22.53 \pm 1.39$ & $21.90 \pm 1.37$ & $29.10 \pm 1.89$ & & & \\
\hline $\mathrm{t}$ & & 10.62 & 10.58 & 5.76 & 0.24 & -2.56 & -2.75 \\
\hline $\mathrm{p}$ & & $<0.001$ & $<0.001$ & $<0.001$ & $>0.05$ & $<0.01$ & $<0.01$ \\
\hline \multicolumn{8}{|l|}{ MCV (fL) } \\
\hline mean \pm S.E. & $83.45 \pm 0.51$ & $84.17 \pm 1.47$ & $79.72 \pm 1.24$ & $84.82 \pm 1.07$ & & & \\
\hline $\mathrm{t}$ & & -0.30 & 2.78 & -1.08 & 2.17 & -0.41 & -3.07 \\
\hline $\mathrm{p}$ & & $>0.05$ & $<0.01$ & $>0.05$ & $<0.05$ & $>0.05$ & $<0.01$ \\
\hline \multicolumn{8}{|l|}{$\mathrm{MCH}(\mathrm{pg})$} \\
\hline mean \pm S.E. & $27.63 \pm 0.19$ & $26.68 \pm 0.50$ & $26.18 \pm 0.34$ & $27.71 \pm 0.38$ & & & \\
\hline $\mathrm{t}$ & & 1.76 & 3.63 & -0.09 & 0.69 & -1.58 & -2.87 \\
\hline $\mathrm{p}$ & & $<0.05$ & $<0.001$ & $>0.05$ & $>0.05$ & $>0.05$ & $<0.01$ \\
\hline \multicolumn{8}{|l|}{ MCHC (g/dL) } \\
\hline mean \pm S.E. & $33.10 \pm 0.06$ & $31.69 \pm 0.16$ & $32.86 \pm 0.27$ & $32.71 \pm 0.39$ & & & \\
\hline $\mathrm{t}$ & & 8.05 & 0.92 & 1.03 & -3.78 & -2.23 & 0.37 \\
\hline $\mathrm{p}$ & & $<0.001$ & $>0.05$ & $>0.05$ & $<0.001$ & $<0.05$ & $>0.05$ \\
\hline \multicolumn{8}{|l|}{ Plt. C (x $\left.10^{9} / \mathrm{L}\right)$} \\
\hline mean \pm S.E. & $232.25 \pm 10.13$ & $283.55 \pm 32.81$ & $119.75 \pm 14.45$ & $252.10 \pm 42.99$ & & & \\
\hline $\mathrm{t}$ & & -0.43 & 5.74 & 0.96 & 4.51 & 1.06 & -2.82 \\
\hline $\mathrm{p}$ & & $>0.05$ & $<0.001$ & $>0.05$ & $<0.001$ & $>0.05$ & $<0.01$ \\
\hline
\end{tabular}

Ferritin levels were significantly elevated in the CRF patients without LC $(\mathrm{P}=0.001)$, the CRF patients who had LC and the LC patients $(\mathrm{P}<0.001)$ compared with the controls (Table 3$)$. The CRF patients who had LC had the highest levels among the patients groups $(\mathrm{P}<0.001)$. Also, the LC patients had significantly higher levels than the CRF patients without LC $(\mathrm{P}<0.01)$.

Erythropoietin. Significantly low EPO levels were found in the CRF patients with and without LC compared with the controls and LC patients $(\mathrm{P}<0.001)$ (Table 3). The CRF patients who had LC had significantly lower EPO levels than those without LC $(\mathrm{P}<0.01)$. Also the LC patients had significantly higher EPO levels than the controls $(\mathrm{P}<0.001)$. No correlation was found between EPO and either of RBCs, Hb, PCV or any of the iron indices in the investigated patient groups.

\section{DISCUSSION}

Chronic renal failure (CRF) is defined as a substantial and irreversible reduction in renal function, over a period of months to less than $20 \%$ of normal. Anaemia is a common complication of CRF with several factors contributing to its pathogenesis $[2,4]$. 
Table 3

Statistical analyses of the results of the iron indices and erythropoietin in the main investigated groups

\begin{tabular}{|c|c|c|c|c|c|c|c|}
\hline & $\mathrm{C}$ & CRF/LC & $\mathrm{CRF}$ & $\overline{\mathrm{LC}}$ & $\begin{array}{l}\text { CRF/LC } \\
\& \mathrm{CRF}\end{array}$ & $\begin{array}{l}\text { CRF/LC } \\
\& \text { LC }\end{array}$ & $\begin{array}{l}\text { CRF \& } \\
\text { LC }\end{array}$ \\
\hline \multicolumn{8}{|l|}{ Iron $(\mu \mathrm{g} / \mathrm{dL})$} \\
\hline mean \pm S.E. & $128.60 \pm 2.72$ & $110.0 \pm 12.53$ & $179.10 \pm 37.76$ & $134.45 \pm 11.05$ & & & \\
\hline $\mathrm{t}$ & & 2.22 & -0.46 & 0.43 & -1.82 & -1.43 & 0.63 \\
\hline $\mathrm{p}$ & & $<0.05$ & $>0.05$ & $>0.05$ & $<0.05$ & $>0.05$ & $>0.05$ \\
\hline \multicolumn{8}{|l|}{ TIBC $(\mu \mathrm{g} / \mathrm{dL})$} \\
\hline mean \pm S.E. & $328.35 \pm 4.96$ & $343.50 \pm 28.0$ & $358.60 \pm 39.50$ & $277.25 \pm 27.62$ & & & \\
\hline $\mathrm{t}$ & & 0.15 & 0.04 & 2.66 & -0.06 & 1.96 & 1.83 \\
\hline $\mathrm{p}$ & & $>0.05$ & $>0.05$ & $<0.01$ & $>0.05$ & $<0.05$ & $<0.05$ \\
\hline \multicolumn{8}{|l|}{ Ferritin $(\mathrm{ng} / \mathrm{mL})$} \\
\hline$\underset{t}{\text { mean } \pm \text { S.E. }}$ & $118.40 \pm 13.08$ & $\begin{array}{l}516.40 \pm 47.43 \\
-8.09\end{array}$ & $\begin{array}{l}189.90 \pm 17.25 \\
-3.30\end{array}$ & $\begin{array}{l}285.25 \pm 30.29 \\
-5.06\end{array}$ & 6.47 & 4.11 & -2.74 \\
\hline $\mathrm{p}$ & & $<0.001$ & 0.001 & $<0.001$ & $<0.001$ & $<0.001$ & $<0.01$ \\
\hline \multicolumn{8}{|l|}{$\mathrm{EPO}(\mathrm{mU} / \mathrm{mL})$} \\
\hline mean \pm S.E. & $12.75 \pm 0.70$ & $4.32 \pm 0.52$ & $6.21 \pm 0.53$ & $22.70 \pm 1.70$ & & & \\
\hline $\mathrm{t}$ & & 8.67 & 4.47 & -6.02 & -2.95 & -11.91 & -7.82 \\
\hline $\mathrm{p}$ & & $<0.001$ & $<0.001$ & $<0.001$ & $<0.01$ & $<0.001$ & $<0.01$ \\
\hline
\end{tabular}

This study attempted to demonstrate some of the biochemical changes associated with the impairment of normal kidney functions in CRF. Some of these changes are of high pathologic importance, as they represent the underlying causes of some diseases ocurring commonly secondary to CRF. Some of the affected biochemical parameters are under dual metabolic control by both the kidney and liver to variable degrees, as has been found on investigating either CRF or LC alone. Association of both diseases together resulted in either intensification or amelioration of these biochemical changes.

In CRF patients with and without LC, BUN and creatinine levels increased significantly as a result of the impaired excretory function of the failed kidneys in those patients, while in LC patients BUN levels decreased significantly due to impaired urea formation by the cirrhotic liver. The role of the kidney in this case was more pronounced than that of the liver.

The elevated levels of ALT, AST and total bilirubin in the CRF patients with $\mathrm{LC}$ indicated that renal failure may have an influence on the liver function, exacerbating the existing cirrhotic state of the liver.

These results are in accordance with those of Woitge et al. [24], who also found significantly increased ALP levels in CRF and in LC patients. They postulated that elevation found in LC was due to the release of the enzyme from the damaged hepatocytes into the plasma; however, the elevation observed in CRF was of non-hepatic origin, and due to increased bone turn-over in those patients.

In CRF patients, the most relevant abnormality is the anaemia and it was thoroughly investigated in this study. CRF patients with and without LC were invariably the most anaemic among the studied subjects. Several investigators reported that CRF patients were severely anaemic $[5,11$, 17,19,25-29]. The results from those authors as well as this study indicated a direct and major role of the failed kidney in the development of this anaemia. Also, positive correlations were found in our study between RBCs, Hb and PCV in all the studied groups.

Our results concerning iron level indicated that CRF patients were not iron deficient. This coincides with the report of Steffensen et al. [30] in which 15 ESRD patients were recruited in the study, all of whom were not iron deficient, regardless of the type of dialysis. On the other hand, in an earlier report by Kariyone and Izuya [31], decreased iron levels were found in CRF patients. In the present study serum iron level 
and TIBC were invalid for detecting irondeficiency anaemia, since the investigated patients were taking iron therapy and many of them had received multiple blood transfusions, which resulted in restoration of their iron levels to normal. However, the presence of anaemia, as measured by other parameters, associated with these apparently normal iron levels in CRF patients suggests poor utilization of iron by the bone marrow [11].

The observed elevated ferritin levels in CRF patients without LC are in accordance with the results of several other studies $[5,11,17,28,30]$. The LC as well as the CRF with LC patients also showed elevated ferritin levels. However, the latter group had the most elevated ferritin levels in this study due to the combined effect of both CRF and LC.

All the investigated CRF patients with and without LC had significantly low EPO levels, whatever the severity of the anaemia. Significantly low EPO levels have been reported in CRF patients by several investigators $[11,15,17,19,25$, 32,33]. On the other hand, Cotes et al. [34] found EPO levels in HD patients that were in the range of normal subjects. Another study by McGonigle et al. [5] reported the presence of high EPO levels in HD patients relative to the controls. However, in all these studies, EPO levels were always relatively low for the degree of anaemia in the investigated subjects and did not increase with increased severity of anaemia.

In our study, only LC patients with intact kidneys showed normal response to their anaemic state manifested in their high EPO levels and milder anaemic state than the CRF patients. This agrees with the results of two reports [25,35] in which elevated EPO levels were found in anaemic LC patients compared with controls. The elevated EPO levels in LC patients is consistent with a compensatory response of the intact kidney, releasing EPO to stimulate the bone marrow which also explaines the milder anaemic state relative to $\mathrm{CRF}$ patients.

Persistence of the anaemic state in CRF patients is primarily due to impaired EPO production as hepatic EPO synthesis failed to compensate. This inevitably led to impaired erythropoie- sis. Although further inhibition of EPO synthesis occurred in patients with both CRF and LC, their anaemic state did not differ significantly from those with CRF only, as judged by their RBCs and $\mathrm{Hb}$ levels, since the major contribution to serum EPO level is of renal origin. Therefore, the anaemia observed in the investigated CRF patients with and without $\mathrm{LC}$ could be considered as renal anaemia. This is confirmed by two main observations. First, iron-deficiency was not a dominant condition among those patients, and many of the patients who had higher serum iron and ferritin levels, and lower TIBC, also had lower EPO levels. Thus it is concluded that poor iron utilization occurred in CRF patients due to the defective erythropoiesis. Poor iron utilization in CRF patients was also reported by Seguchi et al. [11]. The second observation is, that for a given PCV value, a lower EPO level was observed in CRF than in LC patients. A similar observation was reported by Tanebe et al. [32] who found lower EPO levels in renal anaemia than other anaemias of comparable severity.

Additionally, no correlation was found between $\mathrm{EPO}$ and $\mathrm{Hb}$ or PCV in CRF patients in this study. This agrees with several reports, although some have indicated elevated EPO levels in CRF patients $[5,11,17,32,34,36-38]$. No correlation was found between EPO and PCV in LC patients either, although Jensen et al. [27] found an inverse correlation between both parameters in LC patients. However, the presence or lack of correlation between EPO and other parameters varies according to the technique employed in measuring EPO levels. Andre et al. [38] found a positive correlation between EPO and $\mathrm{Hb}$ using the immunoradiometric assay (IRMA). This correlation was not observed in the same group of patients when RIA measured EPO as in this study. This is because RIA measures both biologically active and inactive EPO fragments, indicating higher EPO levels than IRMA.

The present study suggests that EPO deficiency in CRF patients is the true cause of the observed renal anaemia. Since no valid compensatory mechanism exists, as the liver is responsible for the synthesis of about $10 \%$ of that hormone, external supply of the hormone is the only 
effective means to correct this anaemia [39].

\section{References}

[1] Mayne, P.D. (ed.) The kidneys and renal calculi. In: Clinical Chemistry in diagnosis and treatment. Weatherall, Ledingham and Warell, Oxford University Press, $6^{\text {th }}$ ed. (1994) 1-24.

[2] Goldfarb, S. and Ziyadeh, F. Renal diseases and fluid and electrolyte disorders. In: Myers, A.R., (ed.) Medicine N.M.S., Williams \& Wilkins, Waverly Int., USA, $3^{\text {rd }}$ ed., (1997) 279-321.

[3] Fisher, J.W. Mechanism of the anemia of chronic renal failure. Nephron 25, (1980) 106111.

[4] Eschbach, J.W. Nephrology forum: The anemia of chronic renal failure: Pathophysiology and the effects of recombinant erythropoietin. Kidney Int. 35, (1989) 134-148.

[5] McGonigle, R.J.S., Husserl, F., Wallin, J.D. and Fisher, J.W. Hemodialysis and continuous peritoneal dialysis effects on erythropoiesis in renal failure. Kidney Int. 25, (1984) 430-436.

[6] Eschbach, J.W., Egrie, J.C., Downing, M.R., Browne, J.K. and Adamson, J.W. Correction of the anemia of end-stage renal disease with recombinant human erythropoietin. N. Engl. J. Med. 316, (1987) 73-78

[7] Sikole, A., Stojanovic, A., Polenakovic, M., Petrusevska, G., Sadikario, S., Saso, R. and Jovanovski, M. How erythropoietin affects bone marrow of uremic patients. Am. J. Nephrol. 17, (1997) 128-136.

[8] Schwartz, K.A., Dombrouski, J., BurnatowskaHeldin, M. and Mayor, G. Microcytic anemia in dialysis patients: Reversible marker of aluminium toxicity. Am. J. Kidney Dis. 9, (1987) 217223.

[9] Cunningham, J., Sharman, V.L., Goodwin, F.J. and Marsh, F.P. Do patients receiving hemodialysis need folic acid supplements? Br. Med. J. 282, (1981) 1582.

[10] Lewis, S.M. Erythropoiesis. In: Postgraduate hematology. Hoffbrand, A.V. and Lewis, S.M. (eds.) William Heinemann Medical Books Ltd., London, $2^{\text {nd }}$ ed., (1981) 1-34.

[11] Seguchi, C., Shima, T., Misaki, M., Takarada, Y. and Okazaki, T. Serum erythropoietin concentrations and iron status in patients on chronic hemodialysis. Clin. Chem. 38, (1992) 199-203.

[12] Graber, S.F. and Krantz, S.B. Hematopoietic growth factors. Erythropoietin: Biology and clinical use. Hematol. Oncol. Clin. N. Am. 3(3), (1989) 369-400.

[13] Koury, M.J., Bondurant, M.C., Graber, S.E. and Sawver, S.T. Erythropoietin messenger RNA levels in developing mice and transfer of I125erythropoietin by the placenta. J. Clin. Invest. 82, (1988) 154.

[14] Maxwell, P.H., Ferguson, D.J.B., Osmond, M.K., Pugh, C.W., Heryet, A., Doe, B.G., Johnson, M.H. and Ratcliffe, P.J. Expression of a homologously recombined erythropoietinSV40T antigen fusion gene in mouse liver: Evidence for erythropoietin production by its cells. Blood 84, (1994) 1823-1830.

[15] Nissenson, A.R. Erythropoietin overview. Blood Purif. 12(1), (1994) 6-13.

[16] Erslev, A.J. and Besarab, A. Erythropoietin in the pathogenesis and treatment of the anemia of chronic renal failure. Kidney Int. 51, (1997) 622-630.

[17] Teruel, J.L., Marcen, R., Navarro, J.F., Villafruela, J.J., Lucas, M.F., Rivera, M. and Oruno, J. Influence of body iron stores on the serum erythropoietin concentration in hemodialyzed patients. Am. J. Nephrol. 14(2), (1994) 95-98.

[18] Caro, J., Zon, L., Silver, R., Miller, O. and Erslev, A.J. Erythropoietin in liver tissue extracts and in liver perfusates from hypoxic rats. Am. J. Physiol. 244, (1983) E431-E34.

[19] Cassidy, M.J., De Jager, C., Ibrahim, O., Camachio, P. and Robson, S. Peripheral blood mononuclear cells from patients with chronic renal failure release factors which suppress erythropoietin secretion in vitro. Nephrol. Dial. Transplant. 9(7), (1994) 775-779.

[20] Dacie, J.V. and Lewis, S.M. (eds.) Basic hematological techniques. In: Practical hematology. Churchill Livingstone, Longman Group, UK, $7^{\text {th }}$ ed., (1991) 37-65.

[21] Ceriotti, F. and Ceriotti, G. Improved direct specific determination of serum iron and total ironbinding capacity. Clin. Chem. 26, (1980) 327331.

[22] Forman, D.T. and Parker, S.L. The measurement and interpretation of serum ferritin. Ann. Clin. Lab. Sci. 10, (1980) 345-350.

[23] Garcia, J.F., Sherwood, J. and Goldwasser, E. Radioimmunoassay of erythropoietin. Blood Cells 5, (1979) 405-419.

[24] Woitge, H.W., Seibel, M.J. and Ziegler, R. Comparison of total and bone-specific alkaline phosphatase in patients with non-skeletal disor- 
ders of metabolic bone diseases. Clin. Chem. 42, (1996) 1796-1804.

[25] Schlageter, M.H., Toubert, M.E., Padgomiak, M.P. and Najean, Y. Radioimmunoassay of erythropoietin: Analytical performance and clinical use in hematology. Clin. Chem. 36, (1990) 1731-1735.

[26] Pollock, C.A., Wyndham, R., Collett, P.V., Elder, G., Field, M.G., Kalowski, S., Lawrence, J.R., Waugh, D.A. and George, C.R.P. Effects of erythropoietin therapy on the lipid profile in endstage renal failure. Kidney Int. 45, (1994) $897-$ 902.

[27] Jensen, J.D., Jensen, L.W., Madsen, J.K. and Poulsen, L. The metabolism of erythropoietin in liver cirrhosis patients compared with healthy volunteers. Eur. J. Hematol. 54(2), (1995) 111116.

[28] Macdougal, I.C., Tucker, B., Thompson, J., Tomson, C.R.V., Baker, L.R.I. and Raine, A.E.G. A randomized controlled study of iron supplementation in patients treated with erythropoietin. Kidney Int. 50, (1996) 1694-1699.

[29] Meierhenrich, R., Jedicke, H., Voigt, A. and Lange, $H$. The effect of erythropoietin on lactate, pyruvate and excess lactate, under physical exercise in dialysis patients. Clin. Nephrol. 45(2), (1996) 90-96.

[30] Steffensen, G., Aunsholt, N.A. and Povlsen, J.V. Evidence that treatment of ESRD patients with recombinant human erythropoietin induces immunosuppression without affecting the distribution of peripheral blood mononuclear cell subpopulations. Clin. Nephrol. 45(2), (1996) 98103.

[31] Karivone, S. and Izuya S. Relationship between erythropoietin and chronic renal failure. Kidney Dialysis (suppl 1), (1988) 144-148.

[32] Tanebe, M., Teshima, S., Hanyu, T. and Hayashi, Y. Rapid and sensitive method for erythro- poietin determination in serum. Clin. Chem. 38, (1992) 1752-1755.

[33] Morris, K. and Coulthard, M. End-stage kidneys are capable of increased erythropoietin production. Pediatr. Nephrol. 7(3), (1993) 273-275.

[34] Cotes, P.M., Pippard, M.J., Reid, C.D.L., Winearls, C.G., Oliver, D.O. and Royston, J.P. Characterization of the anemia of chronic renal failure and the method of its correction by a preparation of human erythropoietin(r-HuEPO). An investigation of the pharmaco-kinetics of intravenous erythropoietin and its effects on erythrokinetics. Q. J. Med. 70, (1989) 113-117.

[35] Pirisi, M., Fabris, C., Falleti, E., Soardo, G., Toniutto, P., Gonano, F. and Bartolli, E. Evidence for a multifactorial control of serum erythropoietin concentration in liver disease. Clin. Chim. Acta 19, 219(1-2), (1993) 47-55.

[36] Ohigashi, T., Tachibana, M., Deguchi, N. and Tazaki, H. Plasma erythropoietin concentration in chronic renal failure measured by radioimmunoassay. J. Jpn. Soc. Dialysis Ther. 21, (1988) 855-860.

[37] Rhyner, K., Eglie, F., Niemoller, M., Wieczorek, A., Germinger, P. and Vetter, W. Serum erythropoietin werte bei vershiedenen krankheitszustanden. Nephron 51(suppl 1), (1989) 3946.

[38] Andre, M., Ferster, A., Toppet, M., Fondo, P., Dratwa, M. and Bergmann, P. Performance of an immunoradiometric assay of erythropoietin and results of specimens from anemic and polycythemic patients. Clin. Chem. 38, (1992) 758763.

[39] Zhang, F., Ganong, R.F., Richards, G.K. and Brox, A.G. Anemia of chronic renal failure: characterization in the mouse and correction with human recombinant erythropoietin. Nephron 72(4), (1996) 651-654. 


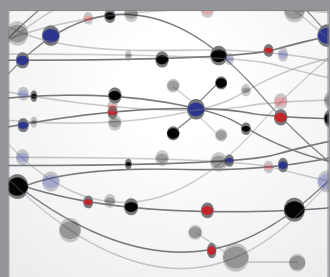

The Scientific World Journal
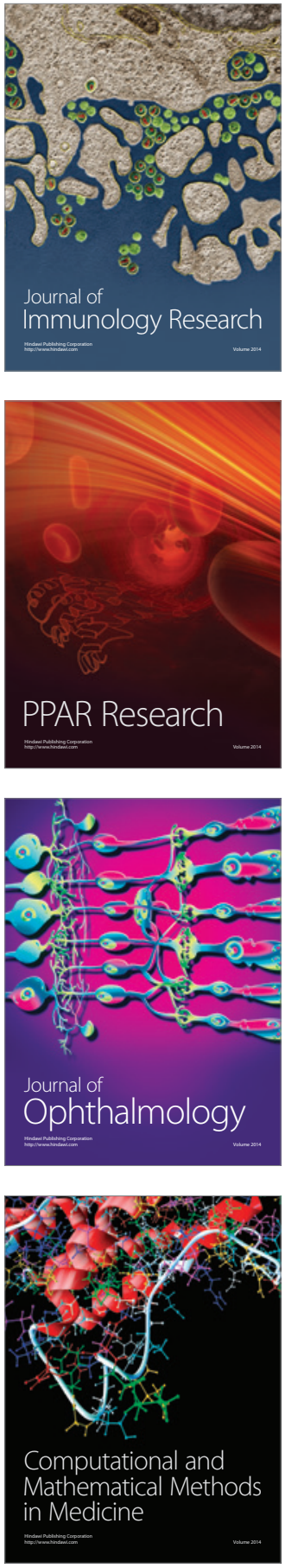

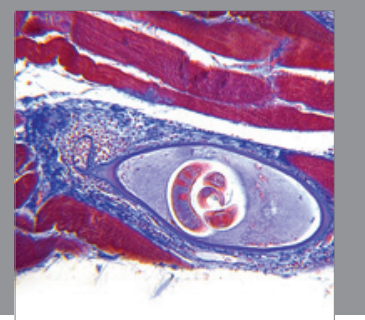

Gastroenterology

Research and Practice
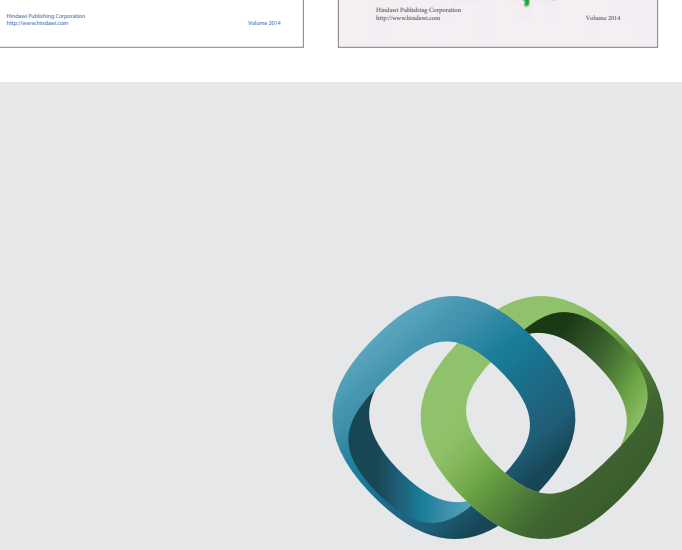

\section{Hindawi}

Submit your manuscripts at

http://www.hindawi.com
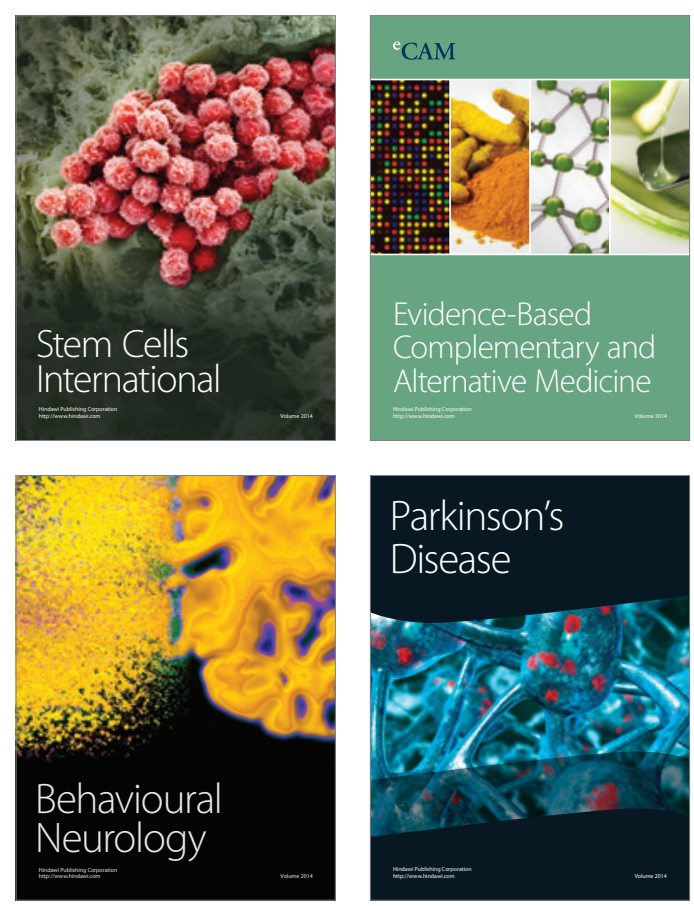

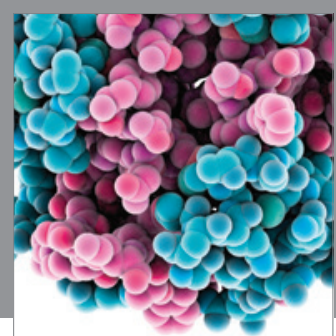

Journal of
Diabetes Research

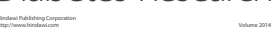

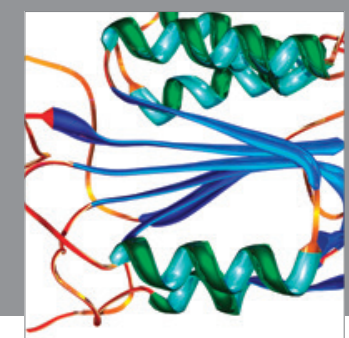

Disease Markers
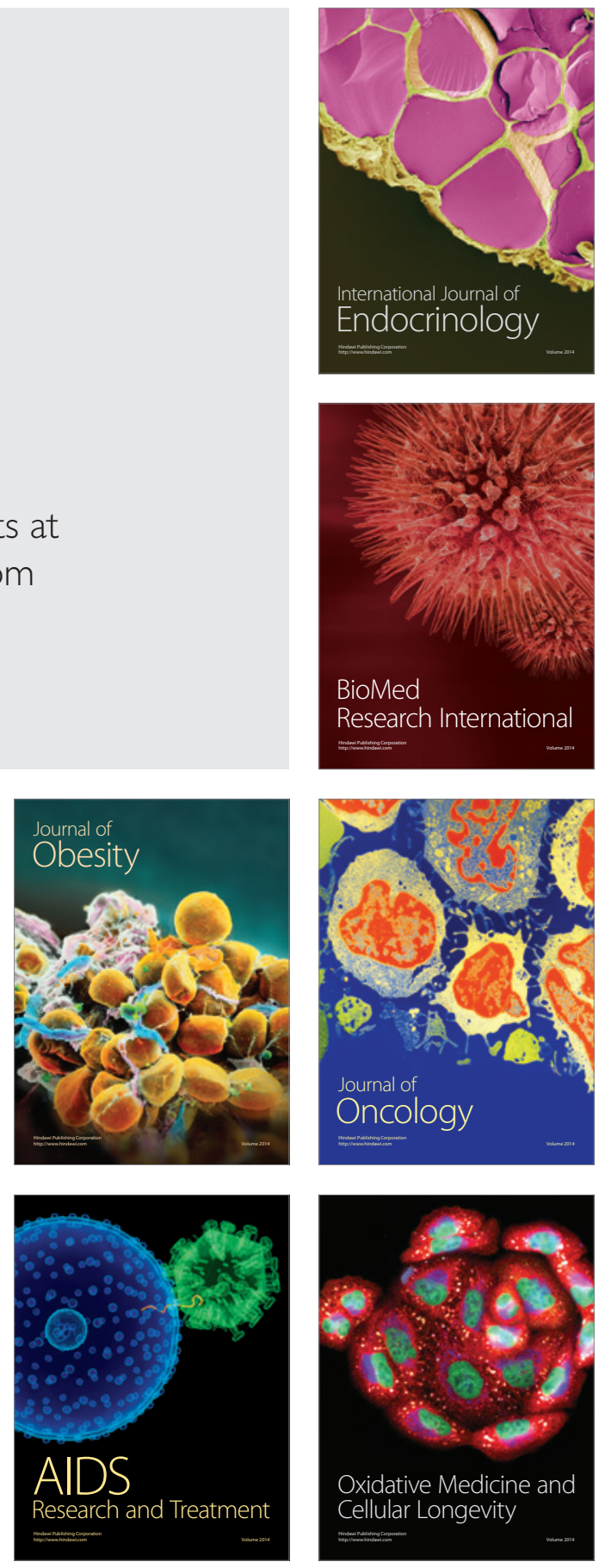